\title{
Pemahaman Masyarakat Dan Perkembangan Kecerdasan Anak; Studi Murid Sekolah Dasar Di Kecamatan Garum Kabupaten Blitar
}

\author{
Riyadus Sholichin, ${ }^{1}$ Wasito $^{2}$ \\ ${ }^{1}$ Pascasarjana Institut Agama Islam Tribakti Kediri, 2 Institut Agama Islam Tribakti Kediri \\ 1ryadssholichin@gmail.com, 2azambagus8@gmail.com
}

\begin{abstract}
This research is framed in a big topic, namely programs, management and school facilities that are of interest to the people of Garum Sub-district, Blitar Regency. Evidently, these topics have an impact on society for how to develop children's intelligence. The community will choose a particular school based on their understanding of children's learning. This also happened in elementary schools in Garum Subdistrict, Blitar District. The problems raised in this study include questions about the understanding of the people of Garum District in Blitar Regency in choosing schools for their children, and the impact of the understanding of the people of Garum District in Blitar Regency on educational institutions. The type of research approach is qualitative-descriptive. In this research, data is collected, then narrated according to the perspective of community development theory. The results of this study Garum District Community Blitar District understands that education is an important means of developing children's intelligence. For this reason, they choose schools with criteria that have the best facilities. This view is the basis for schools to improve themselves into public service institutions.
\end{abstract}

Keywords: Understanding of the People, Intelligence, Education

\begin{abstract}
Abstrak
Penelitian ini dibingkai dalam topik besar yaitu program, managemen dan fasilitas sekolah yang diminati oleh masyarakat Kecamatan Garum Kabupaten Blitar. Terbukti, topik-topik tersebut memberikan dampak kepada masyarakat untuk cara mengembangkan kecerdasan anak. Masyarakat akan memilih sekolah tertentu berdasarkan pemahamannya untuk pembelajaran anak-anaknya. Hal ini yang juga terjadi di sekolah dasar Kecamatan Garum, Kabupaten Blitar. Permasalahan yang diajukan dalam penelitian ini meliputi pertanyaan tentang pemahaman masyarakat Kecamatan Garum Kabupaten Blitar dalam memilih sekolah untuk anaknya, dan dampak pemahaman masyarakat Kecamatan Garum Kabupaten Blitar terhadap lembaga pendidikan.Jenis pendekatan penelitian ini adalah kualitatif-diskriptif. Dalam penelitian ini, data-data dikumpulkan, kemudian dinarasikan sesuai dengan perspektif teori perkembangan masyarakat. Hasil penelitian ini Masyarakat Kecamatan Garum Kabupaten Blitar memahami bahwa pendidikan menjadi sarana penting mengembangkan kecerdasan anak-anaknya. Untuk itu, mereka memilih sekolah dengan kreteria mempunyai fasilitas terbaik.
\end{abstract}


Pandangan inilah menjadi dasar sekolah untuk berbenah diri menjadi institusi pelayan masyarakat

Kata Kunci: Pemahaman Masyarakat, Kecerdasan, Sekolah

\section{Pendahuluan}

Pendidikan bukan hanya sekedar membuat peserta didik pandai menghapal tetapi yang lebih penting ialah menjadikannya sebagai manusia, atau dalam istilah Driyakarya, pendidikan merupakan proses memanusiakan manusia. Pengalaman bersekolah (Pendidikan) dapat mengembangkan keterampilan akademik dan kompetensi serta merubah hidup siswa.Meninjau pada tujuan pendidikan nasional, arah pendidikan di Indonesia adalah untuk mengembangakan kompetensi pada diri siswa. Pendidikan nasional berfungsi engembangkan dan membentuk watak serta peradaban bangsa yang bermartabat dalam rangka mencerdaskan kehidupan bangsa. Untuk mengembangkan dan membentuk watak dan peradaban bangsa yang bermartabat, pendidikan berfungsi mengembangkan segenap potensi peserta didik menjadi manusia yang beriman dan bertaqwa kepada Tuhan Yang Maha Esa, berakhlak mulia, sehat, berilmu, cakap, kreatif, mandiri, dan menjadi warga negara yang demokratis serta bertang-gungjawab.

Pemahaman masyarakat adalah bukan kegiatan berpikir semata, melainkan pemindahan letak dari dalam berdiri di situasi atau dunia orang lain. Mengalami kembali situasi yang dijumpai pribadi lain di dalam erlebnis (sumber pengetahuan tentang hidup, kegiatan melakukan pengalaman pikiran), pemahaman yang terhayati. Pemahaman merupakan suatu kegiatan berpikir secara diam-diam, menemukan dirinya dalam orang lain. Pemahaman Masyarakat dalam pemilihan sekolah untuk anaknya yang bervariasi. Berbagai faktor yang dipertimbangkan dalam memilih sekolah terbaik untuk anaknya. Pemahaman masyarakat juga akan berdampak pada kondisi lembagalembaga pendidikan di Kecamatan garum Kabupaten Blitar. Baik Sekolah Dasar Negri, Madrasah Ibtidaiyah dan Sekolah Dasar Islam. Dampak yang ditimbulkan juga akan bervariasi tergantung dengan cara fikir masyarakat sekitar.

Pemahaman mencakup kemampuan untuk menangkap makna dan arti dari bahan yang dipelajari. W.S Winkel mengambil dari taksonmi Bloom, yaitu suatu taksonomi yang dikembangkan untuk mengklasifikasikan tujuan instruksional. Bloom membagi kedalam 3 kategori, yaitu termasuk salah satu bagian dari aspek kognitif karena dalam ranah kognitif tersebut terdapat aspek pengetahuan, pemahaman, penerapan, analisis, sintesis, dan evaluasi. Keenam aspek di bidang kognitif ini merupakan hirarki kesukaran tingkat berpikir dari yang rendah sampai yang tertinggi.

Koentjaraningrat merumuskan pengertian masyarakat berdasarkan 
empat ciri berikut: (1) Interaksi (2) Adatistiadat, norma-norma, hukum, dan aturan-aturan. (3) Bersifat terusmenerus.(4) Rasa identitas.

Berdasarkan empat ciri di atas, masyarakat diartikan sebagai kesatuan hidup manusia yang berinteraksi sesuai dengan sistem adat-istiadat tertentu yang sifatnya berkesinambungan, dan terikat oleh suatu rasa identitas bersama.

Saat ini, pendidikan di Indonesia diatur melalui Undang-Undang Nomor 20 Tahun 2003 tentang Sistem Pendidikan Nasional. Pendidikan di Indonesia terbagi ke dalam tiga jalur utama, yaitu formal, nonformal, dan informal. Pendidikan juga dibagi ke dalam empat jenjang, yaitu anak usia dini, dasar, menengah, dan tinggi. Pendidikan menengah yang terdiri atas pendidikan menengah umum dan pendidikan menengah kejuruan di jelaskan dalam konsep pendidikan di Indonesia.

Hasan Al-banna mengembangkan konsep tarbiyah Islamiyah, dimana konsep ini diterapkan untuk membina dan mengembangkan potensi yang ada dalam individu secara integral dengan menjadikan manusia sebagai obyek dasar dalam merintis kurikulumnya, serta diimplementasikan dengan langkahlangkah yang jelas, sumber referensinya murni (Al Qur'an).

Al Banna menjelaskan bahwa pendidik bukan hanya dari kalangan alumnus fakultas pendidikan atau mahasiswa yang berhasil menyandar gelar bidang pendidikan, melainkan orang-orang yang memiliki iman, kemudian ruh yang kuat, jiwa yang suci, motivasi yang tinggi, kreatif, perasaan yang lapang, serta pendidik yang mampu mempengaruhi orang lain . Konsep pendidikan nasional yang dikemukakan oleh Ki Hadjar Dewatara sangat membumi dan berakar pada budaya nusantara, antara lain tutwuri handayani, "tripusat" pendidikan (keluarga, sekolah, masyarakat).

\section{Metode}

Pendekatan penelitian yang digunakan dalam penelitian ini adalah pendekatan kualitatif-diskriptif (qualitative-diskription). Bogdan dan Taylor mendefinisikan metodologi kualitatif sebagai prosedur penelitian yang menghasilkan data deskriptif berupa kata-kata tertulis atau lisan dari orangorang dan perilaku yang dapat diamati. Pendekatan ini diarahkan pada latar dari individu tersebut secara holistik (utuh). Jadi dalam hal ini tidak boleh mengisolasikan individu atau organisasi ke dalam variabel atau hipotesis, tapi perlu memandangnya sebagai bagian dari suatu keutuhan. Analisis data kualitatif bersifat induktif, yaitu analisis berdasarkan data yang diperoleh. Menurut Miles \& Huberman analisis terdiri dari tiga alur kegiatan yang terjadi secara bersamaan yaitu: reduksi data, penyajian data, penarikan kesimpulan/verifikasi.

\section{Hasil dan Pembahasan}

Penelitian dilakukan di Kecamatan Garum Kabupaten Blitar. Kecamatan 
Garum memiliki 4 kelurahan dan 5 Desa yaitu Kelurahan Bence, Kelurahan Garum, Kelurahan Sumberdiren, Kelurahan Tawangsari, Desa Tingal, Desa Pojok, Desa Slorok, Desa Sidodadi dan Desa Karangrejo. Desa yang terluas adalah Desa Sidodadi yang sebagian wilayahnya berada di bawah lereng Gunung Kelud.

Partisipan dalam penelitian ini adalah orangtua siswa .Sebanyak dua puluh lima orang yang memiliki anak yang bersekolah di Sekolah Dasar, Madrasah Ibtidaiyah dan Sekolah Dasar berbasis Islam yang tinggal di Kecamatan Garum Kabupaten Blitar. Usia partisipan bervariasi dengan rentang usia antara 24 tahun hingga 50 tahun. Tingkat pendidikan bervariasi dengan tingkat pendidikan lulusan Sekolah Dasar 3 orang, lulusan Sekolah Menengah Pertama ada 8 orang, lulusan Sekolah Manengah atas ada 8 orang, dan lulusan Sarjana Strata-1 5 orang. Jumlah partisipan menurut jenis kelamin ada 12 laki-laki dan 12 perempuan. Dari segi pendapatan dan pekerjaan, ada 1 orang sebagai guru PNS, 4 orang wirausaha, 5 orang buruh dan kuli, 2 orang guru honorer, 5 orang petani, dan 7 orang tidak bekerja atau sebagai ibu rumah tangga. Honor yang diterima para partisipan setiap bulan bervariasi. Honor 0,- rupiah ada 7 orang yang dikarenakan tidak bekerja. 5 orang berpenghasilah rentang 500.000, - sampai 1.000.000,- rupiah ,8 orang berpenghasilan rentang 1.000.000,sampai 3.000.000,- rupiah dan 4 orang berpenghasilan 3.000.000,- rupiah lebih.
Semua partisipan berasal dari suku Jawa dan beragama Islam. Dan mereka memiliki anak 1 hingga 3.

\section{Masyarakat dan Pilihan Sekolah Anak}

Keadaan masyarakat di Kecamatan Garum yang plural membuat masyarakat memiliki karakter-karakter yang berbeda-beda. Keadaan ini membuat mereka menjadi bervariasi dalam memilih sekolah. Banyak telah terjadi pergeseran dalam memilih sekolah untuk memilih sekolah untuk anaknya. Madrasah Ibtidaiyah mampu menjawab persoalan yang ada di masyarakat. Saat sekolah fullday menjadi primadona, mereka yang memiliki pedapatan kelas menengah kebawah bisa memilih sekolah MI menjadi solusi. Madrasah Ibtidaiyah memberi solusi dengan mengadakan sekolah fullday dengan dana minim dan bisa gratis. Kondisi masyarakat sangat berkaitan erat dengan keadaan ekonomi, saat keadaan ekonomi mapan masyarakat cenderung mencari barang-barang bermerek dan segala sesuatu yang terbaik. Termasuk sekolah yang orang tua inginkan untuk anaknya. Tapi masih ada orang yang dengan kondisi ekonomi kurang baik tetap menyekolahkan anak di sekolah berbayar mahal dikarenakan ingin mendapatkan yang terbaik.

Seperti penelitian Redi Zaki Oktama bahwa seberapa besar kontribusi antara kondisi sosial dan kondisi ekonomi baik secara terpisah maupun secara bersamasama, dimana antara kondisi sosial dan ekonomi keluaraga, kontribusi kondisi ekonomi keluagalah lebih dominan 
pengaruhnya terhadap tingkat pendidikan anak.

Sistem zonasi tidak berpengaruh kepada Madrasah Ibtidaiyah dan Sekolah Dasar Swasta. Mereka bebas menerima siswa dari manasaja tanpa harus memakai sistem zonasi. Hal ini berdampak membludaknya pendaftar ke sekolah-sekolah tersebut. Banyak sekolah swasta yang ambil untung daei prokontra adanya simtem zonasi sekolah negri.

Jarak sekolah kurang menjadi hambatan walimurid untuk menyekolahkan anaknya. Disetiap desa di Kecamatan Garum terdapat Madrasah Ibridaiyah. Seperti Desa slorok yang memiliki 4 MI, Pojok 2 MI, Karangrejo 2 MI, Tawangsari 2 MI 1 SDI, Tingal 1 MI, Bence 1 MI 1 SDI, Sidodadi 1 MI 1 SDK, Garum 2 MI, dan sumberdiren 1 SDI. Mereka mengepung sekolah-sekolah negri . Sekolah swasta memiliki layanan antar jemput untuk siswa yang bertempat tinggal jauh dari sekolah. Jadi jarak sekolah di Kecamatan garum tidak mempengaruhi minat walimurid dalam memilih sekolah.

Fasilitas sekolah menjadi tujuan utama masyarakat dalam memilih sekolah yang dituju. Fasilitas yang baik akan membuat anak menjadi maksimal saat belajar. Fasilitas yang mampuni menjadi idaman semua orang untuk mendapatkanya, walau dengan harga yang tidak murah. Sekolah yang memiliki gedung yang berdiri kokoh dan indah dipandang menjadi daya tarik walimurid untuk mensekolahkan anaknya. Keamanan sekolah menjadi alasan utama, apalagi sekarang rawan terjadi kejahatan terhadap anak. Kekhawatiran orang tua sekarang yang kadang agak berlebihan, seperti tidak ingin menyekolahkan anak karena hal-hal yang sepele. Mereka tidak ingin menyekolahkan disebuah sekolah karena ada anak yang nakal, kalau hujan sekolah becek, sekolah terlalu bising atau sekolahnya sepi.

Mengingat pentingnya sarana prasarana dalam kegiatan pembelajaran, maka peserta didik, guru dan sekolah akan terkait secara langsung. Peserta didik akan lebih terbantu dengan dukungan sarana prasarana pembelajaran. Tidak semua peserta didik mempunyai tingkat kecerdasan yang bagus sehingga penggunaan sarana prasarana pembelajaran akan membantu peserta didik, khususnya yang memiliki kelemahan dalam mengikuti kegiatan pembelajaran konvensional seperti ceramah dan tanya jawab. Dukungan fasilitas sarana prasarana mampu membuat kegiatan pembelajaran lebih variatif, menarik dan bermakna yang diharapkan mampu meningkatkan pemahaman dan hasil belajar siswa.

Ada sebuah peralihan budaya dari para walimurid yaitu gedung yang indah bukan hanya bermaksud untuk pembelajaran yang nyaman, tapi juga untuk berfoto. Mereka merasa bangga saat bisa memosting sekolah di sosial media. Kondisi sekolah yang memiliki program atau kharakter yang berbedabeda. Untuk kalangan orang tua yang sudah berumur masih fanatik dengan sekolah negeri, yang mana pernah ada mitos bahwa kalau sekolah di swasta 
tidak bisa diangkat menjadi pegawai. Faktor ini cukup lumrah, karena mereka tidak mendapatkan informasi yang cukup tentang pendidikan. Mereka mengira akan membayar lebih mahal bila menyekolahkan anaknya di sekolah swasta.

Wali murid sekarang cenderung kritis dalam menyikapi kejadian-kejadian yang ada di sekolah. Mereka mengharapkan fasilitas yang memadai. Untuk walimurid dari kalangan muda mereka menggolongkan status akreditasi sebagai bagian penting dari sebuah sekolah. Padahal mereka belum faham apa yang dimaksud dengan akreditasi sekolah. Hanya wali murid yang berpendidikan tinggi atau juga yang berprofesi sebagai guru mampu memahami maksud dari akreditasi sekolah.

Aspek akreditasi yang terdiri dari aspek mutu sekolah yang terdiri dari 8 aspek indikator yaitu memiliki kecenderungan yang tetap dan stabil sehingga para orang tua cenderung akan memilih sekolah yang akreditasinya baik karena ditunjang dengan fasilitas yang diinginkan oleh orang tua masing-masing siswa. Akreditasi sendiri dinilai mampu untuk memberikan informasi mengenai kualitas sebuah lembaga sekolah kepada para wali murid secara menyeluruh, karena pada komponen penilaian akreditasi sekolah yang berkualitas dan dikatan bermutu telah memenuhi beberapa aspek penilaian.

Ilmu pengetahuan dan teknologi memang membuat manusia lebih mudah menyelesaikan persoalan hidup, namun disisi lain berdampak. negatif ketika ilmu pengetahuan dan teknologi tidak lagi berfungsi sebagai pembebas manusia, melainkan justru membelenggu dan menguasai manusia. Pendidikan Islam merupakan pendidikan yang berjiwa budi pekerti dan akhlak yang bertujuan untuk mencapai akhlak yang sempurna. Abdullah Nasih Ulwan juga menyatakan bahwa pendidikan akhlak merupakan serangkaian keutamaan tingkah laku dan naluri yang wajib dilakukan anak didik, dibiasakan dan diusahakan sejak kecil.

Seorang anak, sulit diharapkan untuk dengan sendirinya bertingkah laku sesuai dengan nilai-nilai moral yang berlaku, mengerti apa yang dituntut lingkungan terhadap dirinya, dan sebagainya. Aspek moral seorang anak merupakan sesuatu yang berkembang dan diperkembangkan. Artinya, bagaimana anak itu kelak akan bertingkah laku sesuai atau tidak sesuai dengan nilai-nilai moral yang berlaku, semua itu banyak dipengaruhi oleh lingkungan kehidupan anak yang ikut memperkembangkan secara langsung ataupun tak langsung, aspek moral ini. Karena itu faktor lingkungan besar sekali pengaruhnya terhadap perkembangan moral anak, namun karena lingkungan pertama yang dikenal anak dalam kehidupannya adalah orang tuanya, maka peranan orang tualah yang dirasa paling besar pengaruhnya dalam menanggulangi kenakalan remaja, terhadap perkembangan moral anak, di samping pengaruh 
lingkungan lainnya seperti sekolah dan masyarakat.

Faktor agama membuat mereka memilih sekolah berbasis islami. Masyarakat menyatakan bahwa sudah selayaknya orang islam menyekolahkan anaknya dimadrasah atau SDI. Karena dengan alasan ini sekolah berbasis islam akan maju dan berkembang. Seandainya bukan umat islam yang menyekolahkan anaknya disitu, siapa lagi yang akan menyekolahkan. Jadi rasa saling memiliki karena faktor agama sangat besar.

Selama ini masyarakat dan praktisi pendidikan menganggap bahwa indikator keberhasilan peimbelajaran sebagai inti proses pendidikan adalah ujian nasional. Tapi di kecamatan Garum mulai bergeser. Pandangan seperti ini tidak selamanya keliru tetapi hanya melihat salah satu indikator saja, apabila keberhasilan pendidikan hanya dipandang dari itu saja maka pembelajaran cenderung lebih menekankan pada aspek kognitif semata sehingga aspek afektif dan psikomotorik agak terabaikan. Padahal tujuan pembelajaran adalah siswa menguasai kompetensi yang bermuara pada penguasaan kecakapan hidup atau life skill yang dibutuhkan dalam hidup bermasyarakat. benteng pertahanan religius yang berakar pada hati sanubarinya, kebiasaan mengingat Allah yang telah dihayati dalam dirinya dan intropseksi diri yang telah menguasai seluruh pikiran dan perasaannya, telah memisahkan anak dari sifat sifat negatif, kebiasaan kebiasaan dosa dan akhlak yang rusak, bahkan penerimaannya terhadap setiap kebaikan akan menjadi salah satu kebiasaan dan kesenangannya terhadap keutamaan, dan kemulaiaan akan menjadi akhlak dan sifat yang paling menonjol.

Di sisi lain keberadaan pendidikan tersebut saat ini sangat dibutuhkan oleh masyarakat. Kesadaran masyarakat akan pentingnya pendidikan agama untuk membentuk karakter anak semakin tinggi dewasa ini. Mereka sangat berharap anak yang disekolahkan di SDI/MI memiliki pengetahuan yang seimbang antara agama dan umum. Mereka memilih SDI dengan melihat isi dari pelajaran di SDI yang tidak hanya berdasar materi tetapi juga karakter yang nyata. Oleh karena itu, konten pendidikan yang dipelajari bukan hanya masalah tapi juga sikap. Akhirnya akan terbentuk anak yang pinter juga berkarakter (pinter tur beneh).

Pendidikan karakter di sekolah berbasis islam terasa lebih efektif karena karakter yang terbentuk disesuaikan dengan norma-norma keagamaan yang dewasa ini mulai ditinggalkan. Bila merujuk kepada ciri kehidupan manusia pada era 2000 (era globalisasi) ini ditandai dengan kehidupan yang serba keras, kehidupan yang penuh tantangan dan persaingan (kompetitif) yang ketat disegala lini kehidupan, perpacuan kehidupan kebendaan (materi) yang berorientasi untuk mendapatkan uang sebanyak-banyaknya, kehidupan menjadi bersifat individualisme dengan melemahnya kepedulian sosial, terjadi- 
nya dekadensi moral (kemerosotan akhlak) dan masalah-maslaah penyakit hati manusia lainnya .Kemudian lebih jauh lagi dapat kita amati, dewasa ini para pemuda dan pemudi kita dalam berprilaku lebih banyak meniru-niru yang datang dari Barat, seakan-akan yang mereka lihat dan tonton dari Barat itu patut dicontoh dan diikuti agar jangan ketinggalan zaman. Sehubungan dengan problema tersebutlah maka pendidikan Islam mendapat prioritas utama untuk dibina dan dikembangkan baik melalui pendidikan formal. Saat ini masyarakat sangat membutuhkan pendidikan keagamaan yang lebih banyak porsinya bagi anak-anak mereka. Seiiring kebutuhan tersebut hadirlah SDI/MI tengah masyarakat dengan tawaran jam pendidikan keagamaan yang lebih banyak dan seimbang. Hal ini kemudian yang memberikan minat lebih bagi masyarakat untuk menyekolahkan anaknya pada SDI/MI. Sehingga kebutuhan mereka akan pendidikan yang seimbang antara ilmu umum dan agama dapat terpenuhi tanpa harus repot mencari lembaga pendidikan keagaaman diluar lembaga pendidikan umum (SDN).

Sekolah yang mereka anggap dulu adalah sekolah khusus orang kaya, sekarang sudah tidak. Karena sekarang sudah banyak madrasah-madrasah yang menyelenggarakan fullday tanpa harus membayar mahal. Imbas dari membludaknya siswa yang bersekolah ke SDI Ma'arif dan SDIT sebagai salah satu pemicu madrasah-madrasah melaksana- kan full day school. Mereka tidak ketinggalan dalam hal-hal kurikulum yang dilaksanakan. Menjadikan madrasah-madrasan memiliki program yang sama dengan sekolah mahal tapi berbiaya murah.

Keunggulan sekolah merupakan program yang tersirat dalam visi dan misi sekolah, keunggulan dituangkan dalam program kurikulum sekolah untuk mencapai tujuan sekolah. Keunggulan menciptakan prestasi-prestasi yang diraih oleh sekolah tersebut. Keunggulan sekolah diminati saat sekolah sudah berhasil mendapatkan prestasi-prestasi yang dimaksudkan.

\section{Dampak dari pemahaman masyarakat Kecamatan Garum terhadap lembaga pendidikan}

Dampak dari pemahaman masyarakat yang paling terlihat dari Kecamatan Garum adalah factor religiuitas. Yang mana sekolah-sekolah berlomba-lomba menjadi sekolah berbasis religius. Sekolah Dasar Negri berlomba-lomba mendatangkan tutor-tutor mengaji Alqur' an. Mereka mengubah tradisi SDN yang lebih ke pembelajaran umum menjadi lebih ke karakter religious. Banyak SDN yang siswa putrinya memakai baju panjang, rok panjang dan berjilbab. Memang sikap religius merupakan K1 dalam kurikulum 2013, tapi perlu digarisbawahi bahwa di SDN terdapat berbagai agama. Sekolahsekolah mendirikan mushola di lingkungan sekolah. Tapi karena guruguru ngaji hanya mengajar diwaktu jam 
pelajaran, tidak bisa mengontrol sikap religius murid. Kadang mereka lupa bahwa karakter keagaaman di MI dan SDI berbeda. Karena di MI terdapat muatan-muatan pelajaran yang lain seperti Qur'an Hadist, Aqidah Akhlaq, Sejarah Islam, Fiqh dan Bahasa Arab. Dan pelajaran-pelajaran tadi tidak mungkin di implikasikan di SDN.

Sesuai dengan pernyataan Zuhairini dalam bukunya Filsafat Pendidikan Islam mengemukakan bahwa "Pendidikan Islam adalah usaha yang diarahkan kepada pembentukan kepribadian anak sesuai dengan ajaran Islam atau sesuatu upaya dengan ajaran Islam, memikir, merumuskan dan berbuat berdasarkan nilai- nilai Islam, serta bertanggungjawab sesuai dengan nilai- nilai Islam."Dasardasar Pendidikan Islam paling tidak yaitu terdiri dari Al Qur'an, Sunah dan ijtihad, walaupun sebenarya ijtihad disini hanya pemahaman dan penerjemahan terhadap kedua sumber utama tersebut, namun seperti yang dijelaskan tadi perlunya ijtihad digunakan karena semakin banyaknya permasalahan yang berkembang sekarang ini dalam bidang pendidikan, sehingga ijtihad bisa menjadi sumber lain dalam penyelenggaran pendidikan, karena diperlukannya pemikiran-pemikiran baru yang berhubungan dengan kemajuan ilmu pengetahuan dan teknologi, sehingga perlu adanya terobosan ilmiah sebagai penunjang dalam pengembangan Pendidikan Islam secara sistematis .

Hal ini selaras dengan hakekat pendidikan Islam menurut M. Arifin adalah "usaha orang dewasa muslim yang bertaqwa secara sadar mengarahkan dan membimbing pertumbuhan serta perkembangan fitrah (kemampuan dasar) anak didik melalui ajaran Islam ke arah titik maksimal pertumbuhan dan perkembangannya." Al-Qur'an dan Sunnah Rasul merupakan sumber ajaran Islam, maka pendidikan Islam pada hakekatnya tidak boleh lepas dari kedua sumber tersebut. Dalam kedua sumber tersebut pendidikan lebih dikenal dengan istilah-istilah yang pengertiannya terkait dengan pendidikan, yaitu at-Tarbiyah.

\section{Kesimpulan}

Banyak faktor yang difahami masyarakat Kecamatan Garum kabupaten Blitar dalam memilih sekolah untuk anaknya. Mulai dari faktor kondisi masyarakat, fasilitas sekolah, religiuitas dan harapan yang ingin dicapai. Dari ke empat faktor tersebut faktor religiusitas menjadi faktor yang memahamkan mereka tentang pentingnya bersekolah di lembaga pendidikan yang mengintegrasikan umum dan agama. Banyak Sekolah Dasar Negeri bermetaformosis menjadi sekolah Islam.

Pemahaman masyarakat yang dahulu menginginkan anak bersekolah agar mendapatkan ijazah untuk menjadi pegawai telah bergeser menjadikan sekolah sebagai program karekter anak yang berprestasi dan religi. Sekolah berbayar bukan lagi tabu, masyarakat dengan ekonomi menengah tidak tanggung-tanggung merogoh biaya yang lumayan besar supaya mendapatkan 
pendidikan di sekolah yang dianggap terbaik dengan segala fasilitas dan program-programnya.

\section{Daftar Pustaka}

Arifin, (1991), Ilmu Pendidikan Islam Suatu Tinjauan Teoritis Dan Praktis Berdasarkan Pendekatan Interdisipliner, Jakarta: Bumi Aksara,

Burchinal, M. R \& Peisner-Feinberg, E. Development of Academic Skills from Preschool Through Second Grade: Family and Classroom Predictors of Developmental Trajectories.( Journal School Psychology, 2002) ed.40(5) diakses 24 Juli 2019

Koentjaraningrat, (2003)'Pengantar Ilmu Antropologi 1/koentjaningrat' Rineka Cipta: Jakarta

Kuswarno, Engkus, (2009). Metodologi Penelitian Komunikasi, Fenomenologi: Konsepsi, Pedoman dan Contoh Penelitiannya. Bandung: Widya Padjadjaran, 2009.

Marimba, Ahmad D (1964). Pengantar Filsafat Pendidikan Islam, Bandung : Mizan

Milles dan Huberman, (1992) Analisis Data Kualitatif, Universitas Indonesia Press: Jakarta

Moleong, lexy J. (2007) Metodologi Penelitian Kualitatif. Rev. Ed Remaja Rosda karya Bandung

Oktama ,Redi Zaki (2013) Pengaruh Kondisi Sosial Ekonomi Terhadap Tingkat Pendidikan Anak Keluarga Nelayan Di Kelurahan Sugihwaras Kecamatan Pemalang
Kabupaten Pemalang tahun 2013, Skripsi, Program Sarjana Universitas Negri Semarang: Semarang ,

Pramudia ,Joni Rahmat. Orientasi Baru Pendidikan: Perlunya Reorientasi Posisi Pendidik dan Peserta Didik. Jurnal Pendidikan Luar Sekolah, 2016 (Online),ed.3(1). Diakses 23 Juli 2019.

Seica, Aline \& Maria de Sanches, F C. School Equity: The Student's Perspectives in Diverse School Contexts. (Prodia-Social and Bahavioral Sciencest. 2014) ed.116 hal 2015-2022. Diakses 25 Juli 2019.

Suwarti \& Zainuddin, HM. 2017. Social Studies Learning through Cooperative Script Aplication: Development Strategy of Coorperative and Opinion Appreciation Character for Elementary School Students. Journal Of Development Research. (Online), $\quad$ 1(1): $\quad$ 8-14. (http://journal.unublitar.ac.id/jd r), diakses 17 Agustus 2019

Tauchid, M. (2004) 'Ki Hajar Dewantara: Pahlawan dan Pelopor Pendidikan Nasional'. Majlis LuhurPersatuan Tamansiswa: Yogyakarta.

Winkel, W.S (1996) Pengajaran, Grasindo: Jakarta

Zuhairini, dkk , (1995) Filsafat Pendidikan Islam, Jakarta: Bumi Aksara. 